\title{
Microbiological Assessment of Ready-to-Eat Food Sold in Urban Primary Schools, Douala, Littoral Region, Cameroon
}

\author{
Ariane Laure Wounang Ngueugang ${ }^{1}$, Bonaventure Tientche ${ }^{2,}{ }^{*}$, Smith Asaah ${ }^{2}$, \\ Henri Lucien Fouamno Kamga ${ }^{3}$, Gertrude Bsadjo Tchamba ${ }^{2}$ \\ ${ }^{1}$ Estuary Academic and Strategic Institute (IUEs/INSAM), Douala, Cameroon \\ ${ }^{2}$ Department of Microbiology and Parasitology, University of Buea, Buea, Cameroon \\ ${ }^{3}$ Department of Medical Laboratory Science, University of Bamenda, Bambili, Cameroon
}

\section{Email address:}

Wouni15@gmail.com (A. L. W. Ngueugang), tientche.bonaventure@ubuea.cm (B. Tientche), smithforchu95@gmail.com (S. Asaah), henrikamga2002@yahoo.fr (H. L. F. Kamga), bsadjotchamba@gmail.com (G. B. Tchamba)

${ }^{*}$ Corresponding author

\section{To cite this article:}

Ariane Laure Wounang Ngueugang, Bonaventure Tientche, Smith Asaah, Henri Lucien Fouamno Kamga, Gertrude Bsadjo Tchamba. Microbiological Assessment of Ready-to-Eat Food Sold in Urban Primary Schools, Douala, Littoral Region, Cameroon. International Journal of Food Science and Biotechnology. Vol. 6, No. 2, 2021, pp. 36-44. doi: 10.11648/j.ijfsb.20210602.13

Received: June 15, 2020; Accepted: June 29, 2020; Published: May 212021

\begin{abstract}
Ready-to-eat (RTE) food sold to school going children at school premises can not only provide essential nutrient and energy but also a route for foodborne diseases (FBD). However, there is a paucity of data on microbiological assessment of RTE food sold in primary schools in Douala. The aims of this study was to investigate the microbiological quality of food sold in primary schools and to evaluated the food safety knowledge and practice of vendors to promote a safer school-based food for a better health and well-being of our children. Socio-demographic characteristics and the hygienic practices of 60 RTE food vendors were collected using structured questionnaire. A total of 60 food samples from three different food items (beans, spaghetti and meat) were analyzed for the presence of bacterial and fungal pathogens. Twenty-five grams of each food sample was transferred in to $225 \mathrm{ml}$ of buffered peptone water and homogenized. The homogenates were serially dilute and a volume of $0.1 \mathrm{ml}$ dilution was spread on solid media and incubated at $35-37^{\circ} \mathrm{C}$ for 24 hours and 5 days. Antibiotic susceptibility testing was done for isolated species using Muller Hinton agar and data was entered in excel and exported to SPSS version 20.0. For analysis. The overall prevalence of bacterial pathogens was $23.1 \%$ (26/60) and the total mean enterobacteriaceae count (MEC) was $8.203333 \times 10^{4} \mathrm{CFU} / \mathrm{ml}$ in which the value ranged from $3.4 \times 10^{4}-2.06 \times 10^{5} \mathrm{CFU} / \mathrm{ml}$. The total mean fungal count (MFC) was $1.0341 \times 10^{5} \mathrm{CFU} / \mathrm{g}$ which varied from $0-2.8 \times 10^{5} \mathrm{CFU} / \mathrm{ml}$. Of the total of 60 samples examined, $93.3 \%(56 / 60)$ were found positive for S. aureus of which $15 \%(09 / 60)$ of isolates were contaminated. Citrobacter freundii was isolated in $23.4 \%(14 / 60)$ of RTE food. The greatest number of S. aureus was found in beans and the lowest number in spaghetti. These findings indicated that, the ready-to-eat food sold to primary school children in Douala metropolis represent an important potential health risk to school going children. There is a need for Public Health authority to establish guidelines and standards in order to safeguard the wellbeing of the school going children.
\end{abstract}

Keywords: Ready-to-eat, Microbiological Assessment, Food Vendors, Antibiotic Susceptibility, Douala

\section{Introduction}

Globally, billions of people are at risk of FBD with an estimated 582 million cases, resulting to 420,000 deaths annually. The global burden of foodborne disease was 33 million Disability Adjusted Life Years (DALYs) and the highest estimated burden was observed in Africa [1]. These statistics represent only the tip of iceberg because only a small fraction of those that got ill from infected food actually seek medical care. Food is said to be any substance in a liquid or solid form that can be taken through ingestion to supply essential nutrients which provides energy for growth and 
development of the human body [2]. However, food also served as nutrients for microorganism's growth. These microorganisms consist of bacteria, viruses, parasites and fungi. Microbiological quality of food is an indicator the safety of the food. Recent estimates indicated that there are more than 400 sources of FBD that have been recognized [3]. RTE is food intended by the producer for direct human consumption without the need for cooking or other processing effective to eliminate or reduce to an acceptable level microorganisms of concern [4]. In most primary schools in tropical Africa, RTE are produced unsupervised and without compliance to any food safety guidelines if they exist. These foods are sold in unhygienic surroundings with houseflies, fruit flies and air dust serving as potential sources of contamination.

RTE sold in primary schools are of public health because they have become one of the most common risks associated with the increase in outbreaks of FBD. Several food poisoning outbreaks due to street foods have been documented. For instance, in Brazil between 2000 and 2018, 13,163 FBD outbreaks were reported in the country during this period, involving 247,570 cases and 195 deaths [6]. Likewise, in South Africa, from January 2013 to December 2017, 327 FBDs outbreaks were reported causing illness in 11155 individuals, with $78 \%$ seeking medical care, $4 \%$ required hospital admissions and $0.4 \%$ deaths [7]. The Food and Agriculture Organization of the United Nations (FAO) through the School, Food and Nutrition Framework is promoting a healthy school food environment, an adequate and safe meals, an integrated and effective food and nutrition education throughout the whole school system [8].

Cameroon is an African country known as 'Africa in miniature' largely renowned for its delicious, spicy and wide variety of dishes. The Cameroon Ministry of Public Health has no specific regulations of RTE food [9]. Food vendors in Cameroon usually have very low knowledge of hygienic food handling practices in basic food safety measures and personal hygiene. In Buea, South-West Region Cameroon, the prevalence of feco-oral parasites among street-food vendors was 56.7\% [10]. In Fako Division, Cameroon, Akoachere [11] indicated that hygiene and vegetable preservation practices by vendors were poor and could aggravate contamination with pathogenic bacteria and parasites.

In the recent years, there has been anarchical creation of primary schools in the Douala metropolis, and many without administrative authorizations. Various types of food with objectionable microbiological quality are sold to pupils and teachers during school break periods. Data on microbial quality of food sold in primary schools in Cameroon is lacking, despite the fact that the number of primary schools in cities has skyrocketed. Therefore, the study was aimed at investigating the microbiological quality of RTE food sold in primary schools and to evaluated the food safety knowledge and practice of RTE food vendors to promote a safer school-based meal for a better health and well-being of our children.

\section{Materials and Methods}

\subsection{Study Area and Setting}

The study was carried out in 20 randomly selected primary schools in Douala metropolis. The schools were made up of 10 privates and 10 government owned, distributed in the 5 subdivisions (Administrative units) of the Littoral Region. Douala is a cosmopolitan city and the economic capital of Cameroon.

\subsection{Study Design and Period}

Cross-sectional study was used to assess microbiological quality of food sold to children in selected primary schools in Douala city and assess the knowledge and practices of food vendors on the hygienic food handling practices in basic food safety using a pre-tested questionnaire from March to April 2017.

\subsection{Sample and Data Collection}

The study consisted of 60 RTE food vendors for data collection. A total of 60 (10 from each food item) samples were collected from 3 RTE food items namely: beans, spaghetti and cow meat. The food samples were collected in sterile conical flask and covered with aluminum foil to prevent contamination and transported to the laboratory Pasteur Plus (Nylon, Douala) in a chilled cooler bag. The food samples were processed within 2 hours. The food preparation is shown in table 1.

\subsection{Evaluation of Hygiene and Preservation Practices of Food Vendors}

A face to face interview using pre-tested structured questionnaire was used to collect the demographic characteristics and personal hygiene practices of food vendors. The questionnaire was prepared in English version, translated into French and administered in both languages.

\subsection{Sample Collection and Processing}

Twenty-five grams (25g) of each sample was aseptically weighed and transferred to a stomacher bag to which $225 \mathrm{~mL}$ of sterile $0.1 \%$ buffered peptone water was added. The sample was blended for two minutes at 230 RPM in a stomacher to produce a homogeneous sample. The homogenate was serially diluted $\left(10^{-1}\right.$ to $\left.10^{-2}\right)$ and $0.1 \mathrm{ml}$ of each of the homogenates was then inoculated into corresponding labelled plates of nutrient agar for mesophilic aerobic bacteria, violet Red Bile Lactose (RBL) agar for fecal coliform bacteria, Baird Parker agar for pathogenic staphylococcus aureus, and potato dextrose (LAB M) agar medium for fungi.

The plates for mesophilic aerobic bacteria counts were incubated at $30^{\circ} \mathrm{C}$ for 72 hours, those of fecal coliform incubated at $44^{\circ} \mathrm{C}$ for 48 hours, Baird Parker agar plates incubated at $37^{\circ} \mathrm{C}$ for 48 hours while those for fungal counts were incubated at room temperature $\left(27 \pm 1^{\circ} \mathrm{C}\right)$ for 5 days. In 
addition, selective and differential media (Eosin methylene blue agar, MacConkey agar, Saboureaud agar, Chapman agar, Shighella Salmonella (SS) agar and peptone water, Rappaport-Vassiliadis Soya (RVS) broth, Xylose Lysine Deoxycholate (XLD) agar) were also inoculated and incubated at $35^{\circ} \mathrm{C}$ for $18-24$ hours accordingly [12].

\subsection{Cultural, Morphological and Biochemical Characterization of the Isolate}

The isolates were identified using Bergey's manual of determinative bacteriology [13]. Colony appearance was observed and recorded while Gram's reaction and spore staining were carried out to assess the morphology of the bacterial isolates. In addition, biochemical tests such as indole, citrate utilization, catalase, and coagulase tests were carried out. Lactophenol cotton blue reagent was used for the fungal identification used.

\subsection{Description of Bacteriological Loads of the Sample}

Colonies on each plate was counted by using colony counter after 24 hours and described as colony forming unity per milliliter (CFU/ml) by using the following formula [14].:

$$
\mathrm{CFU} / \mathrm{ml}=\frac{\text { Number of colonies } \mathrm{x} \text { Dilution factor }}{\text { Volume of the sample }}
$$

\subsection{Antibiotic Susceptibility Pattern}

The isolated bacterial species were tested for their sensitivity pattern against the following antibiotic: cefuroxime, ceftriaxone, oxacilline, and penicilline $G$ using the Kirby-Bauer agar disc diffusion method on Mueller-Hinton agar (MHA). Three to five colonies of bacteria were taken and suspended in nutrient broth and incubated for 4 hours at $37^{\circ} \mathrm{C}$. Turbidity of broth culture was compared against 0.5 McFarland turbidity standard. By using sterile cotton swab, the organism in the broth was swabbed over the entire surface of MBA. Antibiotic discs were applied within fifteen minutes using sterile forceps on the surface of medium and incubated at $35-37^{\circ} \mathrm{C}$ for $18-24$ hours.

\subsection{Data Analysis}

All statistical analyses were conducted using SPSS for Windows (version 20.0). The Chi-square test was applied to compare proportions between public and private schools. Analysis of variance (ANOVA).) was used to determine differences in the means bacterial load. Statistical significance was set at $\mathrm{p}<0.05$.

\subsection{Ethical Consideration}

The study was approved by the University of Douala Institutional Review Board. Informed consent was sought and obtained before the collection from the interested food handlers within the selected schools. The identities of the participants involved in the study were kept anonymous and they were free to withdraw anytime during the study.

\section{Results}

\subsection{Socio-characteristics of the RTE Food Vendors in the Primary Schools}

The table 2. shows the characteristics of RTE food vendors in the primary schools in Douala city. In the selected schools, sixty food vendors were assessed and the majority $95.0 \%$ (57/60) were females aged between 30 and 39 years (40\%). The mean age was 39.20 ( $\mathrm{SD}=7.961)$ while the minimum and maximum ages were 24 and 55 years respectively. Concerning the length of years in service, $33.3 \%(20 / 60)$ of study subjects had between 5-9 years of work experience.

\subsection{Hygienic Practice of the Study Participants}

In the study, 93.3\% (56/60) of the food vendors possessed a medical certificate delivered by the Littoral Regional Delegation of Public Health (Table 3). Shockingly, 60.0\% $(36 / 60)$ of them have not heard about FBD and $95.0 \%(57 / 60)$ had not undertaken any formal training on food safety hygiene practice. There was a significant difference between vendors of private and public schools with regards to awareness of FBD $(\mathrm{P}=0.015)$ and job stability $(\mathrm{P}=0.029)$. None of the food vendors wore uniforms, and all handled money while serving food to pupils with bare hands.

\subsection{Bacterial Load of Isolated Bacterial Species from RTE Food Primary School in Douala}

The total mean aerobic mesophilic bacteria count (AMBC) was $9.471667 \times 10^{4} \mathrm{CFU} / \mathrm{ml}$ which varied between $3.0 \times 10^{4}-$ $2.0 \times 10^{5} \mathrm{CFU} / \mathrm{ml}$. The total mean enterobacteriaceae count (MEC) was $8.203333 \times 10^{4} \mathrm{CFU} / \mathrm{ml}$ in which the value ranged from $3.4 \times 10^{4}-2.06 \times 10^{5} \mathrm{CFU} / \mathrm{ml}$ and the total mean staphylococcal count (MSC) was $7.198333 \times 10^{4} \mathrm{CFU} / \mathrm{ml}$ varying from $0-1.95000 \times 10^{5} \mathrm{CFU} / \mathrm{ml}$ (Table 4). A total of 60 of samples from RTE food sold in the primary schools were analyzed, and Enterobacteriacae were present in all.

Staphilococcus aureaus was the most frequent isolate $93.3 \%$ (56/60) followed by salmonella $60.7 \%(37 / 60)$ and Shigella $57.4 \%(35 / 60)$ (Table 5). Citrobacter freundii was present in $23.4 \%(14 / 60)$ of sampled food, Escherichia coli $18.0 \%$ $(11 / 60)$, Enterobacter aeruginosa 5.2\% (5/60) and Klebsiella pneumoniae $6.6 \%(4 / 60)$.

When data were compared, no significant different was observed in the mesophilic aerobic bacteria count $(\mathrm{P}=0.358)$, Enterobacteriacae count $(\mathrm{P}=0.705)$ and Staphylococcal count $(\mathrm{P}=0.696)$ between public and private schools. The greater number of $S$. aureus was found in beans and a lower number in spaghetti. Of the total of 60 samples examined, 93.3\% (56/60) were found positive for $S$. aureus of which 15\% (09/60) of isolates were beyond acceptable levels of microorganisms.

Fungal profile and isolated species in selected foods

The total mean fungal count (MFC) was $1.0341 \times 10^{5} \mathrm{CFU} / \mathrm{g}$ which varied from $0-2.8 \times 10^{5} \mathrm{CFU} / \mathrm{ml}$. Candida species were the most frequent isolate $36.1 \%$ (22/60) followed by Candida albicans $34.4 \%$ (21/60), and Candida dubliniensis 13.1\% $(8 / 60)$. The level of fungal contamination from the total food 
sampled was $33.3 \%(20 / 60)$. Candida species were the

(Figure 1) while candida albicans occurred more in spaghetti predominant fungal species found in beans and meat $8(13.3 \%) \quad 8(13.3 \%)$.

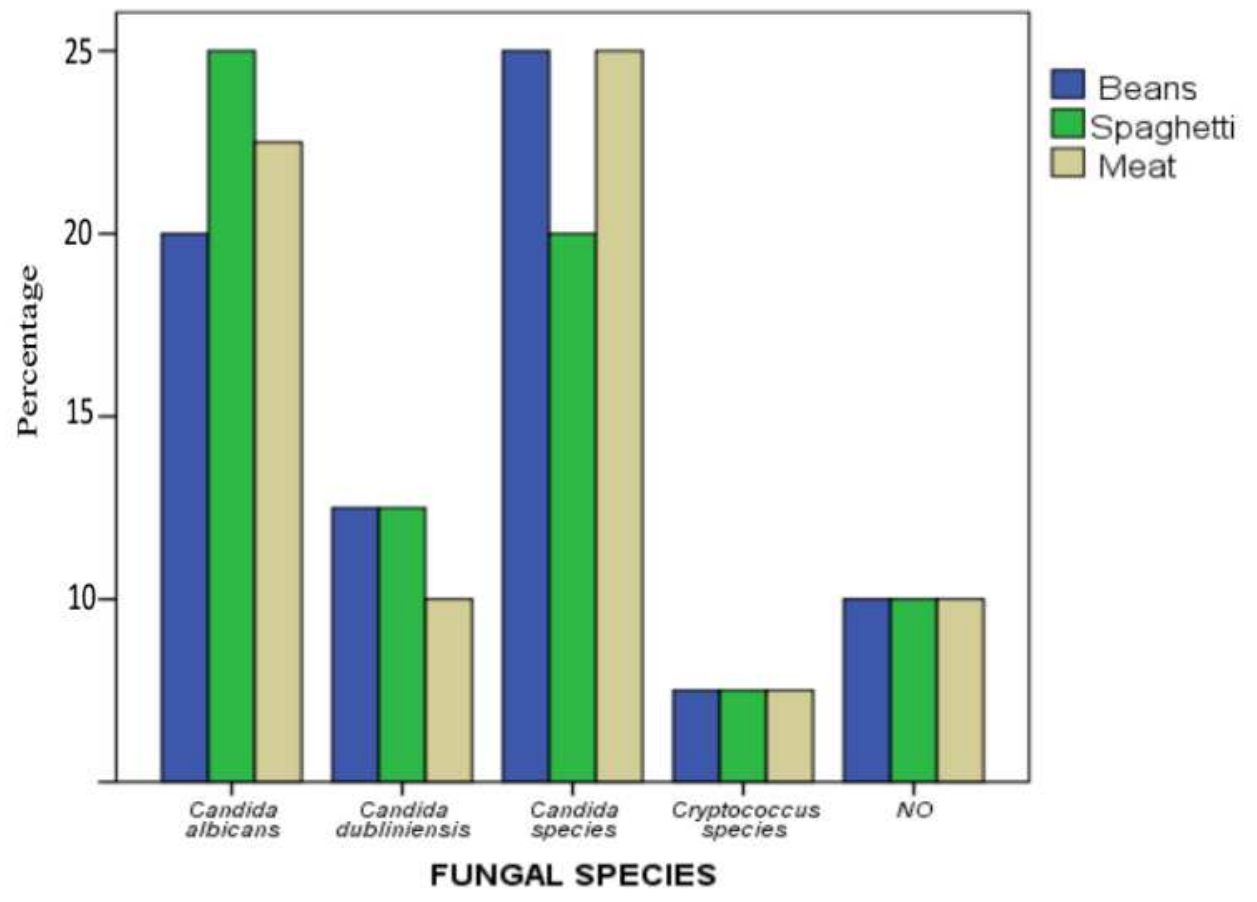

Figure 1. The distribution of fungal isolates with regard to type food.

Antimicrobial susceptibility test

In the present study, Escherichia coli, Salmonella, Klebsiella pneumoniae, and S. aureus showed $100 \%$ sensitivity to ciprofloxacin whereas Escherichia coli. showed $100 \%$ resistance to Erythromycin. S. aureus showed $66.7 \%$ resistance to Penicillin G and 100\% sensitivity to amoxicillin. $C$ feundii was highly resistant to Ceftriaxone (92.8\%).

\section{Discussion}

Health, education, and food security continue to be main targets of United Nations Sustainable Development Goals Initiative. Schools can make a substantial and long-term impact on the above mentioned issues through several entry points and one of them being the provision of safe and nutritious meals to school going children [8]. Owing to the globalization of our food supply and the growing urbanization of the population, ensuring food safety has become an important public health issue. In its efforts to improve food safety, the WHO has introduced the concept of "From farm to plate, make food safe" in 2015 [15]. Thus, the survey was carried out to determine the microbiological quality of RTE sold in 20 primary schools in the metropolis of Douala, in Littoral Region, Cameroon.

In the study, 52.5\% (32/60) of food vendors were aware of the existence of the quality control measures to verify and ensure production of safe food. Majority of food vendors $55.7 \%$ $(34 / 60)$ sold uncovered food thus exposing them to flies and airborne pathogens. Fifty-nine percent (36/60) were ignorant that bacteria cause FBD. However, this is in contrast with results obtained in Sri Lanka [16], which found that $53.7 \%$ of food handlers knew that bacteria cause FBD. With regard to factors affecting the development of bacteria, only $27.9 \%$ $(17 / 60)$ were aware. Shockingly, only $18.8 \%$ (11/60) of respondents mentioned that contaminated water will cause diarrhoea while $24.6 \%(15 / 60)$ attributed diarrhoea to eating with dirty hands. Nearly all food vendors $98.1 \%$ showed the medical certificates as evidence to have undertaken medical examination that exempted them from being a source of any infectious diseases. The Cameroon

Ministry of Public Health emphasized medical examination as a sine qua none condition for anybody to be involved in food trade. However, regular medical check of the vendors was lacking. Once the medical certificate is delivered, the food vendors assume it covers the whole period of an academic year.

The overall prevalence of $23.1 \% \quad(26 / 60)$ bacterial pathogens (above the reference value of $>10^{5} \mathrm{CFU} / \mathrm{ml}$ ) was detected in RTE food sold to primary school children in Douala metropolis. These results are lower than $65 \%$ recorded in Gondar, Ethiopia [17] and $100 \%$ in Kathmandu, India [18]. In the present study, 19 bacteria species namely; Acinetobacter, Citrobacter freundii, Escherichia coli, Enterobacter spp, Enterobacter aerogenes, Enterobacter cloacea, Hafnia alvei, Klebsiella otoxica, Klebsiella pneumonia, Morganella morganii, Proteus mirabilis, Proteus. penneri, Providencia rettgeri, Pseudomonas aeruginosa, Serratia marcescens, Yersinia enterocolitica, Staphilococcus aureus, Salmonella, and Shighella were isolated from the beans, spaghetti and meat. Similar organisms were isolated from RET food sold in primary school children in Abeokuta, South-West Nigeria [19]. 
Table 1. The ingredients and description of food sold in primary schools in Douala city.

\begin{tabular}{|c|c|c|c|c|c|}
\hline $\begin{array}{l}\text { Food } \\
\text { items }\end{array}$ & Description & $\begin{array}{l}\text { Cooking } \\
\text { method }\end{array}$ & Ingredients & Preparation & $\begin{array}{l}\text { Handling } \\
\text { after cooking }\end{array}$ \\
\hline Beans & $\begin{array}{l}\text { Boiled } \\
\text { beans }\end{array}$ & fried & $\begin{array}{l}\text { Tomatoes, green spices (celery, } \\
\text { leeks parsley), onion, red oil), } \\
\text { pepper, seasoning (Maggi cube), } \\
\text { ginger, salt, garlic, bush pepper, } \\
\text { Penja white pepper. }\end{array}$ & $\begin{array}{l}\text {-Wash and boil the beans -Fried the onions and tomatoes } \\
\text { in red oil. Leave it for few minutes to cook - add ground } \\
\text { green spices, garlic, pepper, bush pepper and white } \\
\text { pepper. Allow to cool. - Add salt and seasoning - Pour in } \\
\text { the boiled beans and fried for some } 30 \text { minutes }\end{array}$ & Spoon \\
\hline Spaghetti & $\begin{array}{l}\text { Boiled } \\
\text { spaghetti }\end{array}$ & fried & $\begin{array}{l}\text { Tomatoes, green spices, onions, } \\
\text { pepper, garlic, salt seasoning, } \\
\text { groundnut oil }\end{array}$ & $\begin{array}{l}\text {-Boil spaghetti separately- fried onions and sliced } \\
\text { tomatoes in groundnut oil for about } 45 \text { minutes and add } \\
\text { garlic, pepper, green spices. add seasoning and salt. - } \\
\text { pour in the boiled spaghetti and fried for } 45 \text { minutes }\end{array}$ & $\begin{array}{l}\text { Fork assisted } \\
\text { with hands }\end{array}$ \\
\hline Meat & Stew & fried & $\begin{array}{l}\text { Tomatoes, green spices garlic, } \\
\text { pepper ginger, Penja white pepper, } \\
\text { groundnut oil, }\end{array}$ & $\begin{array}{l}\text {-slice, wash and boil the meat with salt and seasoning. } \\
\text { separately - fried the onions and tomatoes in groundnut } \\
\text { oil for } 45 \text { minutes-add ground spices for few minutes add } \\
\text { the boil meat and allowed to cook for some } 30 \text { minutes. }\end{array}$ & Fork \\
\hline
\end{tabular}

Table 2. Characteristics of RTE food vendors in Primary Schools.

\begin{tabular}{lll}
\hline Characteristics & $\mathbf{n}$ & $\mathbf{\%}$ \\
\hline Sex & 3 & 5 \\
Male & 57 & 95 \\
Female & & 10 \\
Age & 6 & 40 \\
$<29$ & 24 & 36.7 \\
$30-39$ & 22 & 13.3 \\
$40-49$ & 8 & 66.7 \\
$>55$ & & 33.3 \\
Point of Sales & 40 & 33.3 \\
Public schools & 20 & 60.7 \\
Private schools & & 4.9 \\
Source of water for cooking & 20 & 26.7 \\
Municipal Water & 37 & 33.3 \\
Public tap & 3 & 30.0 \\
Well water & & 10.0 \\
Length of Service & 16 & \\
$<4$ Years & 20 & 98.3 \\
5-9 Years & 18 & 1.7 \\
10-15 Years & 6 & 33.3 \\
Ow Years & & 50.0 \\
Ownership of Medical Certificate & 59 & 16.7 \\
Yes & 1 & 96.7 \\
Type of food sold & & \\
Bean & 20 & \\
Spaghetti & 30 & 10 \\
Meat & 59 & \\
Ownership of medical certificate & & \\
\hline
\end{tabular}

The aerobic mesophilic bacteria were found in all RTE food sampled. The aerobic mesophilic bacteria count ranged between $3.5 \times 10^{4}$ and $2.1 \times 10^{5} \mathrm{CFU} / \mathrm{ml}$ hich was lower than those of a study conducted in Jigjiga City in Ethiopia [20]. The presence of saprophytic microorganisms such as aerobic mesophilic bacteria is an indication of poor quality and post heat-processing contamination of RTE food sold in the primary schools [4]. The mean aerobic mesophilic bacteria recorded for each food samples showed that beans $\left(1.03100 \times 10^{5} \mathrm{CFU} / \mathrm{ml}\right)$ contains the highest amount of bacteria followed by meat $\left(1.01300 \times 10^{5} \mathrm{CFU} / \mathrm{ml}\right)$, and spaghetti $\left(7.9750 \times 10^{4} \mathrm{CFU} / \mathrm{ml}\right)$. This is in contrast with study by Sileshi [21]. Though the meat may provide an optimum medium (nutrient abundance) for microbial growth than other food sampled, the present study provides a different scenery.
Considering the maximum acceptable concentration of $10^{5}$ CFU/ml for aerobic mesophilic bacteria [22] in RTE food for consumer protection, $27.3 \%$ (22/60) were contaminated.

The presence of $E$. coli is used as an indicator of possible faecal contamination of food or water to assess the hygiene status of a prepared food. In the study, E. coli was detested in $6.7 \%(4 / 60)$ of sampled RTE food sold to pupils at levels above $10^{5} \mathrm{CFU} / \mathrm{ml}$ [23]. Most of the food vendors (60.7\%) cover a relatively short distance to go and carry water for food preparation. The direct surrounding of the public tap water point, the utensils used to carry water and the personal hygiene of the carriers (Adolescents and older children) may also constitute a source of cross contamination. Water might represent one of the major source of contamination of RTE food sold in the primary schools. The present data indicated 
that only $33.3 \%(20 / 60)$ of food vendors are connected to municipal water supply.

In the present study, the level of Enterobacteriacae contamination was lower (40\%) when compared to the other studies conducted in Ethiopia (61.1\%) [18], and 72\% recorded in Jigjiga [20]. The presence of Enterobactericeae in the study might be attributed to water, poor hygienic practice of food handlers and cross contamination from raw meat, food handlers or food contact surfaces.
The study indicated that $93.3 \%$ of food sampled were found positive for $S$. aureus of which $15 \%$ isolates were beyond the threshold of the International Commission for Microbiological Specification for Food [22]. This is consistent with study conducted in Gondar [17] that revealed a high amount of Staphylococcus aureus in RTE food samples probably due to the fact that food handlers mostly use their hands with poor hand washing habit.

Table 3. Hygienic practice of the RTE food vendors.

\begin{tabular}{|c|c|c|c|c|c|c|c|c|c|c|c|}
\hline \multirow[b]{2}{*}{ Sex } & \multicolumn{2}{|c|}{$\begin{array}{l}\text { Where to store balance } \\
\text { food }\end{array}$} & \multicolumn{2}{|c|}{$\begin{array}{l}\text { Have you heard about } \\
\text { foodborne illness }\end{array}$} & \multicolumn{3}{|c|}{ Source of water for cooking } & \multicolumn{2}{|c|}{$\begin{array}{l}\text { Training program for } \\
\text { food vendors }\end{array}$} & \multicolumn{2}{|c|}{$\begin{array}{l}\text { Existence quality } \\
\text { control measures }\end{array}$} \\
\hline & Fridge & Warming & Yes & No & $\begin{array}{l}\text { Municipal } \\
\text { Water } \\
\text { Supply }\end{array}$ & Public Tap & $\begin{array}{l}\text { Well } \\
\text { Water }\end{array}$ & Yes & No & Yes & No \\
\hline Male & $3(5.0 \%)$ & $0(0.0)$ & $0(0.0)$ & $3(8.3 \%)$ & $0(0.0)$ & $3(5.0 \%)$ & $0(0.0)$ & $0(0.0)$ & $3(8.3 \%)$ & $2(6.2 \%)$ & $1(3.6 \%)$ \\
\hline Female & $53(88.3 \%)$ & $4(6.7 \%)$ & $24(40.0 \%)$ & $33(55.0 \%)$ & $20(33.3 \%)$ & $34(56.7 \%)$ & $3(5.0 \%)$ & $3(8.3 \%)$ & $54(94.7 \%)$ & $30(50.0 \%)$ & $27(45.0 \%)$ \\
\hline Total & $56(93.3 \%)$ & $4(6.7 \%)$ & $24(40.0 \%)$ & $36(60.0 \%)$ & $20(33.3 \%)$ & $37(61.7 \%)$ & $3(5.0 \%)$ & $3(5.0 \%)$ & $57(95.0 \%)$ & $32(53.3 \%)$ & $28(46.7 \%)$ \\
\hline $\begin{array}{l}\text { Public } \\
\text { Schools }\end{array}$ & $37(61.7 \%)$ & $3(5.0 \%)$ & $11(18.3 \%)$ & $29(48.3 \%)$ & $13(21.7 \%)$ & $22(36.7 \%)$ & $2(3.3 \%)$ & $3(5.0 \%)$ & $34(56.7 \%)$ & $25(41.7 \%)$ & $15(25.0 \%)$ \\
\hline $\begin{array}{l}\text { Private } \\
\text { Schools }\end{array}$ & $19(31.7 \%)$ & $1(1.7 \%)$ & $13(20.0 \%)$ & $7(21.9 \%)$ & $7(11.7 \%)$ & $15(25.0 \%)$ & $1(1.7 \%)$ & $0(0.0)$ & $23(38.3 \%)$ & $7(11.7 \%)$ & $13(21.7 \%)$ \\
\hline Total & $56(93.3 \%)$ & $4(6.7 \%)$ & $24(40 \%)$ & $36(60 \%)$ & $20(33.3 \%)$ & $37(61.7 \%)$ & $3(5.0 \%)$ & $3(5.0 \%)$ & $57(95.0 \%)$ & $32(53.3 \%)$ & $18(46.7 \%)$ \\
\hline $\begin{array}{l}\text { Length of } \\
\text { Service }\end{array}$ & & & & & & & & & & & \\
\hline$<4$ Years & $14(23.3 \%)$ & $2(3.3 \%)$ & $5(8.3 \%)$ & $11(18.3 \%)$ & $6(10.0 \%)$ & $9(15.0 \%)$ & $1(1.7 \%)$ & $1(1.7 \%)$ & $15(25.0 \%)$ & $7(21.9 \%)$ & $9(32.1 \%)$ \\
\hline 5-9 Years & $19(31.7 \%)$ & $1(1.7 \%)$ & $10(16.7 \%)$ & $10(16.7 \%)$ & $3(5.0 \%)$ & $15(25.0 \%)$ & $2(3.3 \%)$ & $0(0.0)$ & $20(33.3 \%)$ & $11(34.4 \%)$ & $9(32.1 \%)$ \\
\hline $\begin{array}{l}10-15 \\
\text { Years }\end{array}$ & $28(28.3 \%)$ & $(1(1.7 \%)$ & $7(11.7 \%)$ & $11(18.3 \%)$ & $9(15.0 \%)$ & $9(15.0 \%)$ & $0(0.0)$ & $1(1.7 \%)$ & $17(28.3 \%)$ & $11(34.4 \%)$ & $7(21.9 \%)$ \\
\hline $\begin{array}{l}>15 \\
\text { Years }\end{array}$ & $6(10.0 \%)$ & $0(0.0)$ & $2(3.3 \%)$ & $4(6.7 \%)$ & $2(3.3 \%)$ & $4(6.7 \%)$ & $0(0.0)$ & $1(1.7 \%)$ & $5(8.8 \%)$ & $7(21.9 \%)$ & $7(21.9 \%)$ \\
\hline Total & $56(93.3 \%)$ & $4(6.7 \%)$ & $24(40.0 \%)$ & $36(60.0 \%)$ & $20(33.3 \%)$ & $372(3.3 \%))$ & $3(5.0 \%)$ & $3(5.0 \%)$ & $57(95.0 \%)$ & $32(53.3 \%)$ & $28(46.7 \%)$ \\
\hline
\end{tabular}

Table 4. Mean bacterial and fungal count from food sampled in primary schools Douala city.

\begin{tabular}{|c|c|c|c|c|c|c|c|c|c|c|c|c|}
\hline \multirow{2}{*}{$\frac{\text { Variables }}{\text { Type of school }}$} & \multicolumn{3}{|c|}{ Aerobic mesophilic bacteria count } & \multicolumn{3}{|c|}{ Enterobacteriacae count } & \multicolumn{3}{|c|}{ Staphylococcal Count } & \multicolumn{3}{|c|}{ Fungal count } \\
\hline & Min & Max & Average & Min & Max & Average & Min & Max & Average & Min & Max & Average \\
\hline Public & $3.5 \times 10^{4}$ & $2.1 \times 10^{5}$ & $1.083 \times 10^{5}$ & $3.4 \times 10^{4}$ & $2.06 \times 10^{5}$ & $8.775 \times 10^{4}$ & 0 & $1.6 \times 10^{5}$ & $6.9361 \times 10^{4}$ & 0 & $2.8 \times 10^{5}$ & $9.5777 \times 10^{4}$ \\
\hline \multirow[t]{2}{*}{ Private } & $3 \times 10^{4}$ & $1.8 \times 10^{5}$ & $7.4291 \times 10^{4}$ & $3.9 \times 10^{4}$ & $8 \times 10^{4}$ & $7.3458 \times 10^{4}$ & 0 & $1.95 \times 10^{5}$ & $7.5916 \times 10^{4}$ & 0 & $8.6 \times 10^{5}$ & $11.4875 \times 10^{4}$ \\
\hline & \multicolumn{3}{|c|}{ Total MAMBC $=9.4716 \times 10^{4}$} & \multicolumn{3}{|c|}{$\mathrm{TMEC}=8.2033 \times 10^{4}$} & \multicolumn{3}{|c|}{$\mathrm{TMSC}=7.1983 \times 10^{4}$} & \multicolumn{3}{|c|}{$\mathrm{TFC}=1.034 \times 10^{5}$} \\
\hline \multicolumn{13}{|l|}{ Type of food } \\
\hline Beans & $3.5 \times 10^{4}$ & $2.1 \times 10^{5}$ & $1.031 \times 10^{5}$ & $3.9 \times 10^{5}$ & $1.80 \times 10^{5}$ & $8.55 \times 10^{5}$ & 0 & $1.95 \times 10^{5}$ & $8.47 \times 10^{4}$ & 0 & $8.6 \times 10^{5}$ & $1.264 \times 10^{5}$ \\
\hline Spaghetti & $3.5 \times 10^{5}$ & $1.9 \times 10^{5}$ & $7.975 \times 10^{4}$ & $3.4 \times 10^{5}$ & $2.06 \times 10^{5}$ & $7.82 \times 10^{5}$ & 0 & $1.6 \times 10^{5}$ & $6.42 \times 10^{4}$ & 0 & $2.01 \times 10^{5}$ & $8.74 \times 10^{4}$ \\
\hline \multirow{2}{*}{ Meat } & $3 \times 10^{5}$ & $1.9 \times 10^{5}$ & $1.013 \times 10^{5}$ & $4.2 \times 10^{5}$ & $1.63 \times 10^{5}$ & $8.24 \times 10^{5}$ & 0 & $1.11 \times 10^{5}$ & $6.705 \times 10^{4}$ & 0 & $2.8 \times 10^{5}$ & $9.645 \times 10^{4}$ \\
\hline & \multicolumn{3}{|c|}{ Total $\mathrm{AMBC}=9.4716 \times 10^{5}$} & \multicolumn{3}{|c|}{$\mathrm{TMEC}=8.2033 \times 10^{5}$} & \multicolumn{3}{|c|}{$\mathrm{TMSC}=7.1983 \times 10^{5}$} & \multicolumn{3}{|c|}{$\mathrm{TFC}=1.034 \times 10^{4}$} \\
\hline
\end{tabular}

Table 5. Distribution of bacterial isolates from food samples by type of schools.

\begin{tabular}{|c|c|c|c|c|c|c|c|c|}
\hline & & \multicolumn{3}{|c|}{ Private Schools } & \multicolumn{3}{|c|}{ Public schools } & \multirow[t]{2}{*}{ Total } \\
\hline & & Beans & Spaghetti & Meat & Beans & Spaghetti & Meat & \\
\hline $\mathrm{S} / \mathrm{n}$ & Isolated bacteria & $\mathrm{n}$ & $\mathrm{n}$ & $\mathrm{n}$ & $\mathrm{n}$ & $\mathrm{n}$ & $\mathrm{n}$ & \\
\hline 1 & Acinetobacter & 0 & 1 & 0 & 0 & 0 & 0 & 1 \\
\hline 2 & Citrobacte freundii & 3 & 1 & 4 & 2 & 2 & 2 & 14 \\
\hline 3 & Escherichia coli & 4 & 1 & 2 & 2 & 0 & 2 & 11 \\
\hline 4 & Enterobacter spp & 1 & 1 & 0 & 0 & 0 & 0 & 2 \\
\hline 5 & Enterobacter aerogenes & 1 & 1 & 0 & 1 & 0 & 2 & 5 \\
\hline 6 & Enterobacter cloacea & 1 & 3 & 0 & 0 & 0 & 0 & 4 \\
\hline 7 & Hafnia alvei & 0 & 1 & 0 & 0 & 1 & 0 & 2 \\
\hline 8 & Klebsiella otoxica & 0 & 0 & 1 & 1 & 1 & 0 & 3 \\
\hline 9 & Klebsiella pneumoniae & 0 & 0 & 2 & 0 & 1 & 1 & 4 \\
\hline
\end{tabular}




\begin{tabular}{|c|c|c|c|c|c|c|c|c|}
\hline & & \multicolumn{3}{|c|}{ Private Schools } & \multicolumn{3}{|c|}{ Public schools } & \multirow[t]{2}{*}{ Total } \\
\hline & & Beans & Spaghetti & Meat & Beans & Spaghetti & Meat & \\
\hline 10 & Morganella morganii & 0 & 0 & 0 & 0 & 1 & 0 & 1 \\
\hline 11 & Proteus mirabilis & 0 & 1 & 1 & 0 & 1 & 0 & 3 \\
\hline 12 & Proteus. penneri & 1 & 0 & 0 & 1 & 0 & 0 & 2 \\
\hline 13 & Providencia rettgeri & 0 & 0 & 0 & 0 & 1 & 0 & 1 \\
\hline 14 & Pseudomonas aeruginosa & 1 & 0 & 2 & 1 & 0 & 0 & 4 \\
\hline 15 & Serratia marcescens & 0 & 0 & 0 & 0 & 0 & 1 & 1 \\
\hline 16 & Yersinia enterocolitica & 0 & 2 & 0 & 0 & 0 & 0 & 2 \\
\hline 17 & Staphilococcus aureus & 12 & 10 & 11 & 7 & 8 & 8 & 56 \\
\hline 18 & Salmonella & 4 & 8 & 8 & 6 & 5 & 6 & 37 \\
\hline 19 & Shighella & 9 & 8 & 10 & 1 & 4 & 3 & 35 \\
\hline
\end{tabular}

The presence of a large number of $S$. aureus in the study also indicate poor handling or sanitation of the food vendors. Thus, the consumption of these contaminated food by school going children constitutes a serious health risk. Though, the ICMSF standard for bacteria count is limited at $10^{5} \mathrm{cfu} / \mathrm{ml}$, the probability of production of enterotoxins by $S$, aureus increases when the count goes above $10^{3} \mathrm{CFU} / \mathrm{ml}$ and thus, become resistant to boiling/cooking [23]. Considering this, the prevalence of pathogenic $S$, aureus of food sampled went up to $93.3 \%$. When the levels of $S$. aureus count exceed $10^{5} \mathrm{cfu} / \mathrm{ml}$ in the course of shelf life of a food, there is a risk of sufficient enterotoxin to cause illness [4]. The symptoms of FBD may last a few hours or several days. Typical symptoms include diarrhea, vomiting, abdominal cramps, headaches, nausea, dry mouth, and difficulty swallowing and flu-like symptoms (such as fever, chills, backache [5].

Enterobacter and Citrobacter species were also isolated from the food samples. The presence of theses microorganisms in RTE food is in agreement with other studies in Kenya [24] and Nigeria [25]. Salmonella species contaminated $62.0 \%(37 / 60)$ of food sampled. This contrast with others in Gondar [17] and Harare [26]. where no salmonella was detected in RTE food samples. The presence of Salmonella in the study could be ascribed to inadequate refrigeration due to erratic power supply, insufficient warming or reheating of food. The detection of Shigella in $17.2 \%$ of the RTE food sold to pupils may be potentially be injurious to their health. Shigella is easily destroyed by heat, adequate warming or heating of left-over food is an important control steps for shigellosis.

In the present study, Citrobacter freundii is emerging as an important biological contaminant of RTE food sold in the primary schools in the study area. The bacterium inhabits the environment (soil, water, sewage), food, and the intestinal tracts of animals and humans [27]. C. freundii is also a hospital-acquired pathogen, which caused diarrhea, urinary tract infection, peritonitis, bacteremia, brain abscess, meningitis and highly resistant to antibiotic [28]. Food borne outbreaks causing severe diarrhea ascribed to $C$. freundii, have been reported in China's Henan Province. [29]. The high findings of $C$. freundii in the RTE food sold in the present study could have been as a results of improper washings of various fresh green spices (parsley, leeks and celery) used for the preparation of beans and meat. Once harvested, these spices are transported in trucks without any forms of treatment and stock in open air on bared-floor in markets. Considering the fact that most of the RTE food vendors get their water supply from public tap, theses spices are washed in a basin rather than from the flowing tap water.

The mean fungal count of the food sampled have exceeded the maximum recommended standards set by the ICMSF [22]. Candida species have been reported as one of the most prominent molds occurring in RTE foods. Candida albicans is thought to be the major fungal pathogen of humans. Severe Candida infections are a serious health problem, particularly among immunocompromised individuals [30]. No toxigenic fungi such as Aspergillus, Fusarium, and Penicillium were isolated from the food sold to school going children.

Staphilococcus. aureus, Escherichia coli and Klebsiella pneumoniae isolates showed a higher degree of susceptibility towards ceftriaxone, oxacillin and lesser to penicillin $\mathrm{G}$ and amoxicillin. These findings are consistent with data obtained in Indian [14] and Ethiopia [18]. Salmonella species isolates were all sensitive to ciprofloxacin, and ceftriaxone which are in agreement with the study conducted in Gondar [31]. C. freundii was resistant to ceftriaxone. This is consistent with studies in India [32] and China [33]. The recognition of $C$. freundii to cause various infection is paralleled to the finding that $C$. freundii has become resistant to multiple classes of antibiotics. Thus, as suggested by Liu [34], clinical and environmental strains may be the reservoir of antimicrobial resistance determinants.

Three major limitations can be deduced from the cross-sectional survey. First, the associated risk factors were not ascertained, considering our objectives, Secondly, molecular investigations were not done for the identification of bacteria. Thirdly, owing to the small sample sizes, the results of the study could not be extrapolated to other metropolis in Cameroon.

\section{Conclusion}

These findings indicated that the RTE food sold to primary school children in Douala metropolis represent an important potential health risk to school going children. The high microbial counts recorded from beans, spaghetti and meat are indicative of improper handling of food by the food vendors and overall poor general hygiene. 
Table 6. Antimicrobial susceptibility pattern of bacterial isolates from RTE food sold in primary schools in Douala city.

\begin{tabular}{|c|c|c|c|c|c|c|c|}
\hline $\begin{array}{l}\text { Antimicrobia } \\
\text { ls tested }\end{array}$ & & $\begin{array}{l}\text { Escherichia } \\
\text { coli }(\mathrm{n}=11)\end{array}$ & $\begin{array}{l}\text { Salmonella } \\
(\mathrm{n}=37)\end{array}$ & $\begin{array}{l}\text { Citrobacter } \\
\text { freundii }(n=14)\end{array}$ & $\begin{array}{l}\text { Enterobacter aerogenes } \\
(n=5)\end{array}$ & $\begin{array}{l}\text { Klebsiella pneumoniae } \\
(\mathrm{n}=4)\end{array}$ & S. aureus $\mathrm{n}=9$ \\
\hline \multirow[t]{2}{*}{ Ceftriaxone } & $\mathrm{S}$ & $11(100 \%)$ & $37(100 \%)$ & $1(7.2 \%)$ & $3(60.0 \%)$ & $4(100 \%)$ & $9(100 \%)$ \\
\hline & $\mathrm{R}$ & $0(0.0 \%)$ & $0(0.0 \%)$ & $13(92.8)$ & $2(40.0 \%)$ & $0(0.0 \%)$ & $0(0.0 \%)$ \\
\hline \multirow[t]{2}{*}{ Oxacillin } & $\mathrm{S}$ & $10(90.9 \%)$ & - & - & - & - & $9(100 \%)$ \\
\hline & $\mathrm{R}$ & $1(9.1 \%)$ & - & - & - & - & $0(0.0 \%)$ \\
\hline \multirow[t]{2}{*}{ Pénicillin G } & $\mathrm{S}$ & - & - & - & - & $2(50.0 \%)$ & $3(33.3 \%)$ \\
\hline & $\mathrm{R}$ & - & - & - & - & $2(50.0 \%)$ & $6(66.7 \%)$ \\
\hline Amoxicillin & $\mathrm{R}$ & - & - & - & - & $2(50.0 \%)$ & $0(0.0 \%)$ \\
\hline \multirow[t]{2}{*}{ Erythromycin } & $\mathrm{S}$ & $0(0.0 \%)$ & & & & & $9(100 \%)$ \\
\hline & $\mathrm{R}$ & $11(100 \%)$ & & & & & $0(0.0 \%)$ \\
\hline Ciprofloxacin & & & $\begin{array}{l}37(100 \%) \\
0(0.0 \%)\end{array}$ & & & & $9(100 \%)$ \\
\hline \multirow[t]{2}{*}{ Tetracycline } & $\mathrm{S}$ & $11(100 \%)$ & $32(86.5)$ & & & & \\
\hline & $\mathrm{R}$ & $00(0.0)$ & $5(13.5)$ & & & & \\
\hline
\end{tabular}

There is a need for Public Health authority to step into the issue in order to safeguard the well-being of the school going children.

\section{Author Contributions}

ALWN, designed the study and collected the data. BT, designed the study, analyzed the data and drafted the primary manuscript. SA, carried out field activities and analyzed the data. GBT collected the data and review the manuscript. HLFK designed the study and coordinated the study. All authors read and approved the submitted version.

\section{Acknowledgements}

We would like to express our gratitude to school principals, teachers and food vendors for their contribution to the study.

\section{Conflicts of Interest}

The authors declare that they have no competing interests.

\section{References}

[1] World Health Organization. "WHO estimates of the global burden of foodborne diseases: foodborne disease burden epidemiology reference group 2007-2015”. 2015.

[2] Daniyan, S. Y., and Nwokwu, O. E, "Enumeration of microorganisms associated with the different stages of bread production in Futmin bakery", International Research of Pharmacy, (2). 88-91. 2011.

[3] Awol, N., Nigusse, D., and Ali, M, "Prevalence and antimicrobial susceptibility profile of Salmonella and Shigella among food handlers working in food establishment at Hawassa city, Southern Ethiopia," BMC research Notes, (12). 7-12. 2019.

[4] Health Protection Agency. "Guidelines for Assessing the Microbiological Safety of Ready-to-Eat Foods", London: Health Protection Agency, 2009.

[5] Addis, M., Sisay, D, “A Review on Major Food Borne Bacterial Illnesses”, Journal of Tropical Diseases, (3). 176. 2015.
[6] Jéssica, A. F. F. F., Wilma, S. G. V. B., Daniele, F. M., Deborah, H. M. B., and Uelinton, M. P, "Overview of Foodborne Disease Outbreaks in Brazil from 2000 to 2018”, Foo5s, (8), 434, 2019.

[7] Shonhiwa, A. M., Ntshoe, G., Essel, V., Thomas, J., McCarthy, $\mathrm{K}$, "A review of foodborne diseases outbreaks reported to the outbreak response unit, national institute for communicable diseases, South Africa, 2013-2017" Abstracts / International Journal of Infectious Diseases, 79 (S1), 1-150. 2019.

[8] Food and Agriculture Organization of the United Nations "Nutrition guidelines and standards for school meals A report from 33 low and middle-income countries" Rome, 2019.

[9] Pouokam, G. B., Foudjo, B. U. S., Samuel, C., Yamgai, P. F., Silapeux, A. K., Sando, J. T., Atonde, G. F. and Frazzoli, C, "Contaminants in Foods of Animal Origin in Cameroon: A One Health Vision for Risk Management "from Farm to Fork" ". frontiers in Public Health, (5). 197. 2017.

[10] Assob, J. C. N., Nde P. F., Nsagha, D. S., Njimoh, D. L., Nfor, O., Njunda, A. L., Kamga, H. L. F, "The incidence of feco-oral parasites in street-food vendors in Buea, south-west region Cameroon" African Health Sciences, (12), 2012.

[11] Akoachere, J-F. T. K., Tatsinkou, B. F., and Nkengfack, J. M, "Bacterial and parasitic contaminants of salad vegetables sold in markets in Fako Division, Cameroon and evaluation of hygiene and handling practices of vendors" BMC Research Notes, (11).100. 2018.

[12] Kabiru, M. R., And Madaki, H. M, "Assessment of the microbiological quality of some locally made candies sold at some primary schools at Sharada, Bayero" Journal of Pure and Applied Sciences, (1). 10. 285-289. 2017.

[13] Bergey's manual of determinative bacteriology, 9th edition

[14] Sharma, I. and Mazumdar, J. A, “Assessment of bacteriological quality of ready to eat food vended in streets of Silchar city, Assam, India", Indian journal of medical microbiology, 32 (2), 169-171. 2014.

[15] World Health Organization "Food Safety: What you should know". Regional Office for South-East Asia, Indraprastha Estate, Mahatma Gandhi Marg, New Delhi 110 002, India, 2015.

[16] Galgamuwa, LS., Iddawela, D., Dharmaratne, S. D, "Knowledge and practices of food hygiene among food handlers in plantation sector, Sri Lanka" International Journal of Scientific Reports, 2 (12), 304-311. 2016. 
[17] Amare, A., Worku, T., Ashagirie, B., Adugna, M., Getaneh, A, "Bacteriological profile, antimicrobial susceptibility patterns of the isolates among street vended foods and hygienic practice of vendors in Gondar town, Northwest Ethiopia: a cross sectional study" BMC Microbiology, (19), 120. 2019.

[18] Tuladhar, R. and Singh A, "Bacterial Analysis Food of Kathmandu” Journal Natural History Museum, (26), 1-9 2012.

[19] Afolabi, O. R., Oloyede, A. R., Obuotor, T. M., Adegoke, L. M., Adeleke, A. O., Komonibo, T. O, "Microbiological Safety of Ready-to-eat Foods Sold in Primary Schools in Abeokuta, South-West Nigeria", Journal of Science \& Sustainable Development, (5), 65-73. 2012.

[20] Bereda, T. W., Emerie, Y. M., Reta, M. A., Asfaw, H. S, "Microbiological safety of street vended foods in Jigjiga City, eastern Ethiopia". Ethiopian Journal of Health Science. 26 (2): 163-72. 2016.

[21] Sileshi, S, "Bacteriological quality of food in Arba Minch University, Abaya Campus Student's Cafeteria”. International Research Journal of biological science. 7 (1), 6-14, 2018.

[22] International Commission for Microbiological Specification in Food (ICMSF) "Microorganisms in foods. 7. Microbiological Testing in Food Safety Management". Kluwer Academic/Plenum Publishers, New York, USA. 20-40. 2002.

[23] Reis, T. V. M., Coutinho de Oliveira, T. L., Andrade Boari, C. and Hilsdorf P. R, "Isolamento de coliformes, estafilococos e enterococos de leite cru provenientes de tanques de refrigeração por expansão comunitários: identificação, ação lipolítica e proteolítica". Ciência e Tecnologia de Alimentos, 28 (3), 753-760. 2008.

[24] Githaiga GM. "Microbial quality, strain distribution and Enterotoxigenicity of selected food borne pathogens in relation to the hygienic practices in industrial area, Nairobi, Kenya": Faculty of Agriculture, College of Agriculture and Veterinary Sciences, University of Nairobi; 2012.

[25] Akusu, O., Kiin-Kabari, D., Wemedo, S, "Microbiological quality of selected street vended foods in Port Harcourt metropolis, Rivers state, Nigeria". Sky Journal of Food Science, 5 (2). 08-11.2016.

[26] Kwiri, R., Winini, C., Tongonya, J., Gwala, W., Mpofu, E., Mujuru, F, "Microbiological safety of cooked vended foods in an urban informal market: a case study of Mbare Msika, Harare, Zimbabwe". 2014.

[27] Wang, J. T, Chang, S. C., Chen, Y. C., and Luh, K. T, "Comparison of antimicrobial susceptibility of Citrobacter freundii isolates in two different time periods." The Journal of Microbiology, Immunology and Infection. 33 (4): 258-262. 2000.

[28] Chen, H., Wang, Y., Zhang, J., Yunsheng, C., Minglin, W, "Isolation and identifiation of Citrobacter spp. from the intestine of Procambarus clarkii". Journal of Fisheries Research, 2 (1): 1-6. 2017.

[29] Bai, L., Xia, S., Lan, R., Lui, L., Yel, C., Wang, Y, Isolation and characterization of cytotoxic, aggregative Citrobacter freundii. PLoS One, 7 (3): e33054. 2012.

[30] Trofa, D., Ga'cser, A., and Nosanchuk, J. D, "Candida parapsilosis, an Emerging Fungal Pathogen", Clinical Microbiology Reviews, 606-625, 2008.

[31] Garedew-Kifelew, L., Wondafrash, N., Feleke, A, "Identifcation of drug-resistant Salmonella from food handlers at the University of Gondar, Ethiopia", BMC Research Notes. (7), 545. 2014.

[32] Mohanty, S., Singhal, R., Sood, S., Dhawan, B., Kapil, A., Das, B. K, "Citrobacter infections in a tertiary care hospital in Northern India. Journal of Infectious", 54 (1).58e64. 2007.

[33] Liu, L-H., Wang, N-Y., A Ying-Jung, A. W., Lin, C-C., Lee, C-M., Liu, C-P, "Citrobacter freundii bacteremia: Risk factors of mortality and prevalence of resistance genes", Journal of Microbiology, Immunology and Infection, (51), 565e572. 2018.

[34] Liu, L., Lan, R., Liu, L., Wang, Y., Zhang, Y., Wang, Y. and Xu, J. "Antimicrobial Resistance and Cytotoxicity of Citrobacter spp. in Maanshan Anhui Province, China". Frontiers in Microbiology, (8).1357. 2017. 